

\title{
Quality Improvement in the management of people with epilepsy and Intellectual Disability: the development of clinical guidance
}

\begin{abstract}
Introduction

This clinical guidance looks at the specific concerns of delivery of medical treatment for people with epilepsy and intellectual disability (ID). People with ID have not been included in licencing drug trials of AEDs. However, this population has an over representation of seizure comorbidity, treatment resistance and polypharmacy while also being vulnerable to not having their views considered.

Areas Covered

This review summarises the current most robust evidence available for the use of licenced AEDs people with epilepsy and ID. The article will provide practical evidenced based clinical information to help prescribers choose the most appropriate AED from the drugs discussed. The article highlights other important individualised factors to consider before initiating or changing antiepileptic medication.

\section{Expert Opinion}

A 'traffic light' coding system is applied to commonly used AEDs based on the level of evidence and expert clinical experience. Managing epilepsy in the ID population requires specialist care. Treatment plans need to be holistic and tailored to accommodate an individual's co-morbidities, concurrent medications, general health, social and environmental status. There is a need for large quality trial data to assess the most suitable AEDs on seizure control and quality of life in this population with complex needs.
\end{abstract}




\subsection{Introduction}

There has been a firm and sustained 'call for action' to improve the delivery of care to people with epilepsy and intellectual disability (ID) in the UK and other parts of the world. In 2014 the Task Force on epilepsy and ID of the International League against Epilepsy (ILAE) published a White Paper that proposed a framework to enhance the delivery of supports for people with epilepsy and ID and identified four major areas of concern [1]. One of them related to the diagnosis and medical treatment of people with epilepsy and ID (Table 1). Specific concerns were identified in relation to the prescription and monitoring of antiepileptic drugs (AEDs), particularly the associated side effects. The recommended actions from the White Paper included the need for a position paper establishing best practice in the identification and monitoring of side effects associated with AEDs, with specific attention to be paid to drug interactions [1].

Table 1: Areas of concern in the Diagnosis and Medical Treatment of people with epilepsy and ID [1]

- Misdiagnosis - complexity of presentation and co-morbidities

- Communication during consultation

- Challenges in accessing appropriate investigations

- Medication concerns - side effects, monitoring treatment success

- Transfer of knowledge between all stakeholders

- Availability of accessible information

\subsection{Epilepsy and ID}

The prevalence of epilepsy in the general population has been reported to be between 0.6 and $1 \%$ [2]. In contrast, up to one-quarter of individuals with ID will have a diagnosis of epilepsy and the prevalence of epilepsy increases with the severity of ID [3]. Many people with epilepsy and ID show a poor response to AEDs [4]. Treatment resistant epilepsy (defined as failure of adequate trials of two tolerated and appropriately chosen and used AEDs [5]), ID, and neurological deficit suggest a multifactorial aetiology and are often associated with multiple physical and psychological co-morbidities [6, 7]. In order to address the barriers the ID population face in receiving appropriate seizure care, we need to first understand the complexity of presentation and individual needs of people with ID (Table 2). As epilepsy is such a common co-morbidity for people with ID, many doctors involved in the care of people with ID are also involved in the assessment and treatment of seizures in people with ID. Those who are not directly involved must have a basic understanding of the impact seizures and its treatment may have on an individual holistically, specifically regarding mental health and behaviour $[8,9]$.

Table 2: The complexity of epilepsy in the ID population [8]

Seizures are usually present in early life

Higher rates of genetic/structural brain damage

Higher rates of generalised seizures

Lower rates of seizure freedom with first AED treatment 
More likely to have life-long seizures

Higher rates of SUDEP/status epilepticus

Higher rates of AED prescription and polypharmacy

More likely to be prescribed and to use rescue medication

Increased rates of Emergency Department attendance because of seizures

Multiple co-morbidities common

Communication, choice, and capacity complexities

Difficult to measure treatment success

Specific issues with chewing, swallowing problems, constipation, and percutaneous endoscopic gastrostomy (PEG) feeding

\subsection{The development of clinical guidance}

In 2017 in the UK, Faculty of Psychiatry of Intellectual Disability of the Royal College of Psychiatrists developed a strategic response to address some of the identified concerns. The first step was to develop a tiered model (Bronze, Silver, and Gold) of professional competencies for psychiatrists working with people with epilepsy and ID. While directed at Psychiatrists it can be an apt template for any professional group which indulges in managing people with epilepsy and ID.

Each category of competency is aligned to the National Institute of Health and Care Excellence (NICE) outcome indicators for epilepsy and the Scottish Intercollegiate Guidelines Network (SIGN) guidance. Bronze level competency is the minimum expected standard for all psychiatrists in ID on a continuum that extends to more expert care encompassed in the silver and gold competencies. Bronze competency is focused on the basic management of epilepsy, encompassing diagnosis and treatment (non-complex), effects of treatment and associated side-effects, and awareness and mitigation of direct and indirect risks associated with ID and epilepsy. The development and approach to application of this model is set out in the RCPsych College Report (CR203), good practice guidance on the management of epilepsy in adults with intellectual disability [9].

The next step in the Faculty's strategic response was the development of a position statement for the prescription of AEDs for people with epilepsy and ID, as called for by the ILAE White paper (Kerr et $a l, 2014)$. The scope of the position paper was to establish best practice for the management of epilepsy with AEDs and the identification of their side effects. Specific attention is paid to drug-drug and drug-disease interactions because of the high level of co-morbid conditions and associated polypharmacy experienced by this population, particularly the associated mental health conditions. This summary of the evidence was designed to help inform prescribing clinicians in relation to the 
attaining of the Bronze/Silver/Gold competencies laid out in the College Report (CR203) [9]. The full scope of this report is collated in in the RCPsych College Report (CR206) [8].

The working group of the International Society for the Scientific Study of Intellectual and Developmental Disorders (IASSIDD) has developed consensus guidelines on the management of epilepsy in adults with ID [10]. However, to date there are no specific national guidelines for the management of epilepsy in people with ID in the UK (or any other countries that we are aware of), and of specific relevance none that relate to the professional grouping of doctors who work with people with ID. Both NICE and SIGN recognise the complexities associated with prescribing to this group but there is a limited evidence base [11]. Cochrane reviews examining pharmacological interventions for epilepsy in people with ID highlight the lack of high-quality evidence examining the efficacy, side-effect profile, and safety of AEDs for people with ID [12,13]. The complexity of presentation of epilepsy with ID warrants specific considerations, particularly the potential for adverse effects of AED treatment upon cognition and behaviour. As a result of the limited robust research available, the choice of medication is largely based upon data extrapolated from trials in the general population with epilepsy. There is more robust evidence to guide decisions around prescribing in a few specific seizure syndromes (epileptic encephalopathies) associated with the development of ID including Lennox-Gastaut and Dravet syndromes [13, 14, 15].

There is a strong case for the delivery of guidance specific to psychiatric practice for the management of epilepsy in people with an ID. This paper outlines the methodology and key content of these guidelines.

\subsection{Strategic response to improve quality of care}

A working committee was formed from members of the Faculty of Psychiatry of ID Executive Committee. The Executive Committee consists of elected representatives and co-opted members of the Faculty. The working group included doctors with a primary role of supporting people with ID with a range of experience in epilepsy. Special advisors such as neurologists and nurses with expertise in epilepsy were identified to support the group. Objectives for the strategy were discussed and set by the working group (Table 3 ).

Table 3: Objectives-set by the working group

- To identify the current evidence base on prescribing AEDs to people with ID.

- To identify the general and specific needs and requirements of people with ID who have epilepsy focusing on the impact of AEDs.

- To identify and deliver a matrix to evaluate current AEDs to combine evidence and expert clinician perspective.

- To identify a prescribing framework for doctors to use while managing or consulting to a person with ID and epilepsy.

- To provide an overview of the side effect complexity and how to mitigate them.

- To highlight the practical pitfalls in co-prescribing with other medication particularly psychotropics.

- To consider using to self-measure and develop epilepsy competencies as proposed in the epilepsy strategy document (CR203) [9] 
- To provide a template for a national dialogue with Epilepsy Specialist Nurses, Neurologists and GPs to develop a unified strategy to improve outcomes in epilepsy for people with ID.

A comprehensive literature search was conducted based upon a recent review article conducted to investigate AED treatment in adults with ID [11]. The working group considered National guidance and best practice documents from NICE, SIGN, and the recent ILAE White Papers on epilepsy and ID. The evidence in the report is not a systematic review of the literature. The working group arrived at a consensus on the most appropriate evidence to include within the guidance as a resource of examples for clinicians.

The evidence available for each AED was graded according to the criteria set out by the Canadian Task Force on the Periodic Health Examination (1979) [16]. The working group propose a rating system for current AED medication using a 'traffic light' coding system. The 'traffic-light' coding for each AED was agreed by consensus of the working group based on current evidence, clinical experience, and expert views from the field.

A draft document was circulated to the working committee and a wider group of identified experts in the field external to the ID Faculty, including three expert neurologists specialising in epilepsy, two academics, one epilepsy specialist nurse, two specialists in ID and epilepsy, one general practitioner with special interest in epilepsy, one pharmacist, one psychiatrist in General Adult Psychiatry and three psychiatrists in Psychiatry of ID. A first round of extensive feedback was gathered and assimilated into the document.

An update on the planned structure of the document was presented to the Faculty of Psychiatry of ID Executive Committee. Approval was gained to continue in the direction identified and specific issues were highlighted. The report was circulated for a second round of reviews to all members of the working group and invited experts. On completion of this process, the report was submitted to the Royal College of Psychiatrists oversight committee for review and quality assurance. As part of the larger College review the document was circulated for feedback to all its other faculties and special interest groups. A third round of feedback was received from the Psychopharmacology Committee, Neuropsychiatry Committee, the Northern Ireland Division and the Faculty of Old Age Psychiatry and incorporated into the final report document (CR206) [8] Alongside feedback was also collected from the ILAE British Chapter.

\subsection{Choosing the most appropriate AED}

From the data available for commonly prescribed AEDs in people with ID the results were graded by a traffic light system integrating research evidence on efficacy, side effect profile, and safety alongside clinical experience from experts in the field. The information was synthesised and presented in an accessible format for prescribers to easily access when weighing up prescribing choices in complex clinical scenarios (Table 4). This data provides information of the AEDs with the most robust evidence and should not be considered as exclusive.

RED - Only use in exceptional circumstances

AMBER-Could be considered if benefits outweigh risks or as second line

GREEN- Needs to be considered as first line treatment

Table $4 \quad$ Evidence for the suitability of commonly used AEDs in the ID population [8]

\begin{tabular}{|c|c|c|c|c|c|}
\hline Drug & $\begin{array}{c}\text { ID } \\
\text { specific }\end{array}$ & $\begin{array}{c}\text { Type of } \\
\text { evidence }\end{array}$ & Commentary & $\begin{array}{c}\text { Level of } \\
\text { evidence* }\end{array}$ & Suitability in ID*** \\
\hline
\end{tabular}




\begin{tabular}{|c|c|c|c|c|c|}
\hline & evidence & & & & \\
\hline Lamotrigine & $\begin{array}{l}\text { Motte et } \\
\text { al 1997 } \\
\text { [17] } \\
\text { Buchanan } \\
\text { 1995 [18] } \\
\text { [20] } \\
\text { McKee et } \\
\text { al 2006 } \\
\text { Gidal et al } \\
\text { 2000 [19] }\end{array}$ & $\begin{array}{l}\text { LGS specific, } \\
\text { RCT using } \\
\text { placebo } \\
\\
\text { M } 34 \\
\text { majority } \\
\text { showed > } \\
50 \% \\
\text { improvement } \\
\text { larger study } \\
\text { analysis of a } \\
\text { improvement } \\
20 \% \\
\text { worsening } \\
\text { No } 44,45 \%> \\
\end{array}$ & $\begin{array}{l}\text { Under power } \\
\text { Under power } \\
\text { Unclear of } \\
\text { specific } \\
\text { characteristics } \\
\text { to decide who } \\
\text { would improve } \\
\text { and who } \\
\text { would worsen }\end{array}$ & I & $\begin{array}{l}\text { Green } \\
\text { Pros } \\
\text { One of the most well } \\
\text { studied molecules in } \\
\text { both general and ID } \\
\text { populations } \\
\underline{\text { Cons }} \\
\text { Possible interactions } \\
\text { Slow titration to dose }\end{array}$ \\
\hline
\end{tabular}




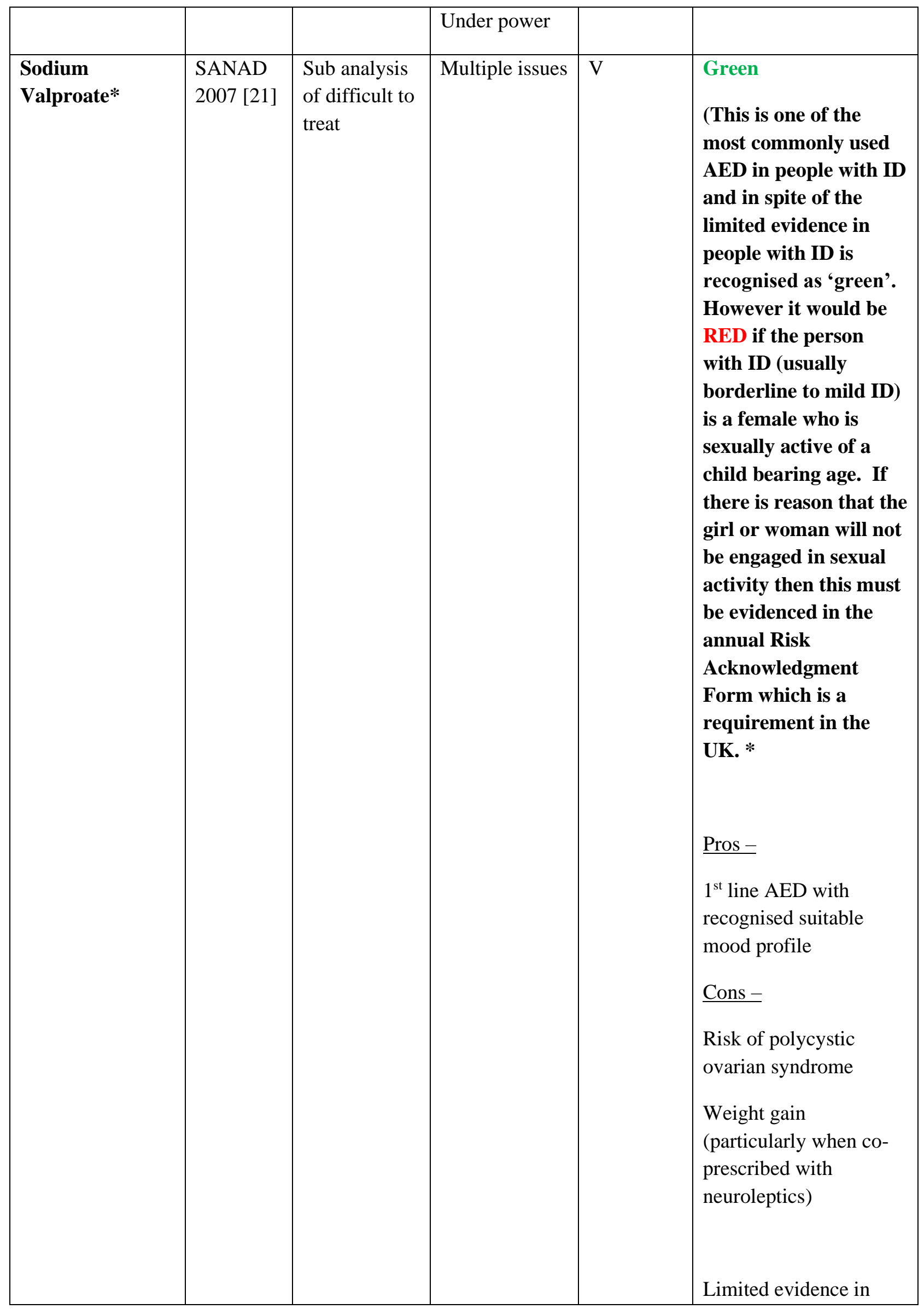




\begin{tabular}{|c|c|c|c|c|c|}
\hline & & & & & people with ID \\
\hline Levetiracetam & $\begin{array}{l}\text { Kelly et } \\
\text { al. 2004 } \\
\text { [22] } \\
\\
\text { Brodtkorb } \\
\text { et al 2004 } \\
\text { [23] }\end{array}$ & $\begin{array}{l}\mathrm{N}=64 \\
\text { Observationa } \\
1 \text { study of } \\
\text { adjunct LEV } \\
38 \% \text { seizure } \\
\text { free } \\
\\
n=184 \text { ID } \\
n=56 \\
\text { equally } \\
\text { effective } \\
\\
\text { N=42 } \\
\text { Open label } \\
\text { prospective } \\
\text { multicentre } \\
\text { study (Add- } \\
\text { on) }\end{array}$ & $\begin{array}{l}\text { Improved } \\
\text { seizure control } \\
\text { in majority and } \\
\text { carer } \\
\text { satisfaction } \\
\text { Study focus } \\
\text { was on } \\
\text { behaviour - } \\
\text { worse in ID } \\
\text { Statistically } \\
\text { significant } \\
\text { reduction in } \\
\text { mean seizure } \\
\text { frequency } \\
\text { No long term } \\
\text { impact on } \\
\text { behaviour }\end{array}$ & III & $\begin{array}{l}\text { Green } \\
\text { Pros- } \\
\text { Does not interact with } \\
\text { other commonly } \\
\text { prescribed medication } \\
\text { in people with ID } \\
\text { Has been well studied } \\
\text { in the general } \\
\text { population and is } \\
\text { considered } 1^{\text {st }} \text { line } \\
\text { medication } \\
\text { Cons } \\
\text { Needs more studies in } \\
\text { ID } \\
\text { Concerns exist about } \\
\text { behavioural and } \\
\text { psychiatric side effects } \\
\text { though the phenomenon } \\
\text { might be more common } \\
\text { in general population } \\
\text { than ID due to titration } \\
\text { differences }\end{array}$ \\
\hline Brivaracetam & $\begin{array}{l}\text { Andres et } \\
a l, 2018 \\
{[25]}\end{array}$ & $\begin{array}{l}\mathrm{N}=33 \\
\text { Retrospective } \\
\text { study, } \\
\text { treatment } \\
\text { resistant } \\
\text { group }\end{array}$ & $\begin{array}{l}19 \% \text { responder } \\
\text { rate }(50 \% \\
\text { reduction in } \\
\text { seizure } \\
\text { frequency } \\
37 \% \text { retention } \\
\text { rate } \\
\text { New } \\
\text { occurrence of } \\
\text { aggressive } \\
\text { behaviour } \\
(39 \%)\end{array}$ & III & $\begin{array}{l}\text { Amber } \\
\text { Pros- } \\
\text { Does not interact with } \\
\text { other commonly } \\
\text { prescribed medication } \\
\text { in people with ID } \\
\text { Cons- } \\
\text { Limited data, only small } \\
\text { retrospective } \\
\text { investigations available } \\
\text { Concerns about } \\
\text { behavioural and }\end{array}$ \\
\hline
\end{tabular}




\begin{tabular}{|c|c|c|c|c|c|}
\hline & $\begin{array}{l}\text { Willems } \\
\text { et al, } \\
2018[26]\end{array}$ & $\begin{array}{l}\mathrm{N}=44 \\
\text { Multicentre } \\
\text { retrospective } \\
\text { cohort study } \\
\text { Patients with } \\
\text { epileptic } \\
\text { encephalopat } \\
\text { hies }\end{array}$ & $\begin{array}{l}50 \% \text { seizure } \\
\text { reduction long } \\
\text { term in } 43 \% \\
\text { patients } \\
16 \% \text { adverse } \\
\text { behavioural } \\
\text { changes }\end{array}$ & & $\begin{array}{l}\text { psychiatric adverse } \\
\text { effects (aggression) } \\
\text { remain }\end{array}$ \\
\hline Topiramate & $\begin{array}{l}\text { Kerr et al } \\
2005[27]\end{array}$ & $\begin{array}{l}\text { RCT Double } \\
\text { blind to } \\
\text { placebo } \\
\mathrm{n}=57 \\
28 / 29 \text { - } 32 \% \\
\text { reduction in } \\
\text { seizure } \\
\text { frequency in } \\
\text { treatment } \\
\text { group vs. } 1 \% \\
\text { in placebo }\end{array}$ & $\begin{array}{l}\text { No negative } \\
\text { impact on } \\
\text { behaviour was } \\
\text { found in the } \\
\text { RCT } \\
\text { Under power }\end{array}$ & I & $\begin{array}{l}\text { Amber } \\
\text { Pros - } \\
\text { Reasonable evidence in } \\
\text { ID } \\
\text { No major interactions } \\
\text { other that Oral } \\
\text { contraceptives } \\
\text { Cons - } \\
\text { Though the RCT found } \\
\text { no impact on behaviour } \\
\text { the real world } \\
\text { experience suggests } \\
\text { that it can be considered } \\
\text { to have an impact on } \\
\text { mood and behaviour } \\
\text { Weight loss (not always } \\
\text { a negative) }\end{array}$ \\
\hline Gabapentin & $\begin{array}{l}\text { Crawford } \\
\text { et al } 2001 \\
{[28]}\end{array}$ & $\begin{array}{l}\text { Add on } \\
\text { Randomised } \\
\text { comparative } \\
\text { open study } \\
\text { with } \\
\text { Lamotrigine } \\
\text { - no } \\
\text { difference }\end{array}$ & $\begin{array}{l}\text { Under } \\
\text { powered } \\
\text { Side effects of } \\
\text { aggression }\end{array}$ & II & $\begin{array}{l}\text { Amber } \\
\text { No definitive details of } \\
\text { efficacy or potential for } \\
\text { harm }\end{array}$ \\
\hline Perampanel & $\begin{array}{l}\text { Shankar } \\
\text { et al } 2017\end{array}$ & $\begin{array}{l}\text { Retrospective } \\
\text { case series, } \\
\mathrm{N}=144(\mathrm{Gen}\end{array}$ & $\begin{array}{l}>50 \% \text { seizure } \\
\text { improvement } \\
\text { in } 24 \% \text { mild }\end{array}$ & III & Amber \\
\hline
\end{tabular}




\begin{tabular}{|c|c|c|c|c|c|}
\hline & [29] & $\begin{array}{l}\text { pop } 71, \text { mild } \\
\text { ID } 48, \text { mod } \\
\text { to profound } \\
\text { ID 48) }\end{array}$ & $\begin{array}{l}\text { ID, } 26 \% \\
\text { moderate to } \\
\text { profound ID. } \\
\text { Safe in people } \\
\text { with ID and } \\
\text { better tolerated } \\
\text { than general } \\
\text { population. } \\
\text { Mental health } \\
\text { side effects. }\end{array}$ & & $\begin{array}{l}\text { Pros- } \\
\text { Does not usually } \\
\text { interact with other } \\
\text { commonly prescribed } \\
\text { medication in people } \\
\text { with ID } \\
\text { Considered an } \\
\text { alternative in treatment } \\
\text { resistant epilepsy } \\
\text { Cons } \\
\text { Concerns exist about } \\
\text { behavioural, cognitive } \\
\text { and mental side effects }\end{array}$ \\
\hline Lacosamide & $\begin{array}{l}\text { Flores et } \\
\text { al } 2012 \\
{[30]}\end{array}$ & $\begin{array}{l}\text { Open } \\
\text { population } \\
\text { cohort } \\
\mathrm{N}=40318 \% \\
\text { ID sub } \\
\text { analysis } \\
\text { No } \\
\text { differences } \\
\text { between ID } \\
\text { vs. non ID }\end{array}$ & Case selection & IV & $\begin{array}{l}\text { Amber } \\
\underline{\text { Pros- }} \\
\text { Is considered to have a } \\
\text { favourable profile } \\
\underline{\text { Cons }} \\
\text { Limited published data } \\
\text { to date }\end{array}$ \\
\hline Carbamazepine & $\begin{array}{l}\text { Kaski et } \\
\text { al } 1991 \\
{[31]}\end{array}$ & $\begin{array}{l}\text { Improved } \\
\text { efficacy } \\
\text { using slow } \\
\text { release } \\
\text { preparation } \\
\text { vs. standard }\end{array}$ & $\begin{array}{l}\text { No direct } \\
\text { evidence of } \\
\text { tolerance or } \\
\text { efficacy }\end{array}$ & $\begin{array}{l}\text { II (but } \\
\text { unrelated) }\end{array}$ & $\begin{array}{l}\text { Amber } \\
\text { Pros-- } \\
\text { long standing AEDs, } \\
\text { recognised } 1^{\text {st }} \text { line } \\
\text { treatment } \\
\text { Cons - } \\
\text { No direct evidence of } \\
\text { efficacy in ID } \\
\text { Multiple drug } \\
\text { interactions with other } \\
\text { commonly prescribed } \\
\text { medication in people } \\
\text { with ID such as other } \\
\text { AEDs and } \\
\text { psychotropics }\end{array}$ \\
\hline
\end{tabular}




\begin{tabular}{|c|c|c|c|c|c|}
\hline & & & & & $\begin{array}{l}\text { Associated with } \\
\text { hyponatraemia } \\
\text { especially if used in } \\
\text { conjunction with } \\
\text { diuretics or SSRIs }\end{array}$ \\
\hline Phenytoin & none & None & - & $\mathrm{V}$ & 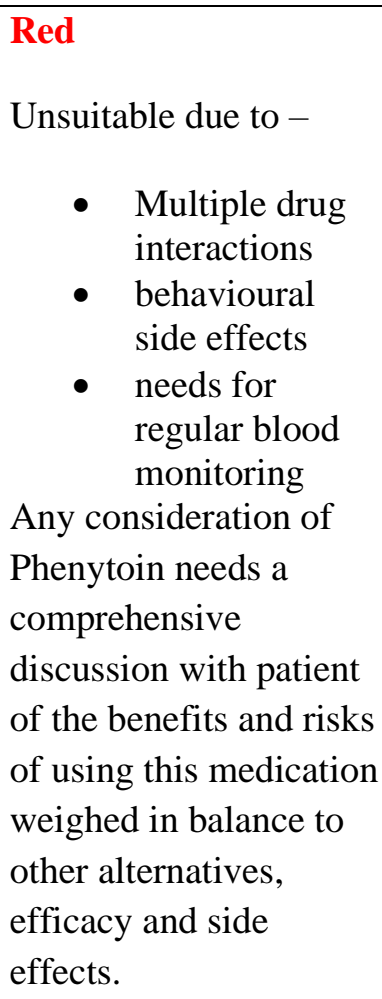 \\
\hline Phenobarbitone & none & none & - & V & $\begin{array}{l}\text { Red } \\
\begin{array}{l}\text { Unsuitable due to - } \\
\text { - } \quad \begin{array}{l}\text { Cognitive } \\
\text { issues }\end{array} \\
\text { Multiple drug } \\
\text { interactions } \\
\text { behavioural } \\
\text { side effects } \\
\text { needs for } \\
\text { regular blood } \\
\text { monitoring }\end{array} \\
\begin{array}{l}\text { Any consideration of } \\
\text { phenobarbitone needs a } \\
\text { comprehensive } \\
\text { discussion with patient } \\
\text { of the benefits and risks } \\
\text { of using this medication } \\
\text { weighed in balance to }\end{array}\end{array}$ \\
\hline
\end{tabular}




\begin{tabular}{|l|l|l|l|l|}
\hline & & & & $\begin{array}{l}\text { other alternatives, } \\
\text { efficacy and side } \\
\text { effects. }\end{array}$ \\
\hline
\end{tabular}

*In 2018 the Medicines and Healthcare products Regulatory Agency (MHRA) reviewed the guidance on valproate medicines. Valproate containing medicines are contraindicated in girls or women of child bearing age unless they participate in the Pregnancy Prevention Programme.

\subsection{Other AEDs}

To date, the evidence for the safety, tolerability and efficacy of other AEDs in people with ID including pregabalin, tiagabine, stiripentol, eslicarbazapine, oxcarbazepine, retigabine, euthosuximide, and zonisamide is limited. There are specific epilepsy syndromes and epileptic encephalopathies where some of these AEDs are used under specialist supervision that is beyond the scope of this review.

\subsection{Rescue Medication}

Benzodiazepines e.g. buccal (oromucosal) midazolam are widely used as emergency rescue medication and there is good supporting evidence for their use. The prescription of buccal midazolam should be accompanied by specific strict guidelines on how and when to administer and be reviewed regularly. Midazolam is specifically used to help halt seizures in the community and is especially useful due to its buccal administration [32]. Clobazam is a useful adjunct for short periods to manage clusters of seizures [33]. Best practice guidelines for the treatment of prolonged/clusters of epileptic seizures in the community has been published by ESNA (Epilepsy Nurses Association) in association with the ILAE and RCPsych and should be followed. There are several cautions to consider when prescribing benzodiazepines for epilepsy including the potential negative effects on cognition, potential for sedation, and possible tolerance to the drugs [34].

\subsection{Conclusion}

The management of epilepsy in people with ID needs to be individualised and based on a good understanding of the combination of factors related to ID and those related to epilepsy. The first principle of epilepsy management should be patient safety. Two key risk areas to be considered are bathing and sudden unexpected death in epilepsy (SUDEP). Every individual should have a personalised epilepsy care plan including a formal assessment of risk that is reviewed regularly. A holistic assessment of the person, their condition, their specific risks and an appropriate treatment plan for both rescue medication and regular treatment needs to be produced, understood, and communicated to all clinicians and carers. Evidence about the effectiveness of treatment and the potential side effects is not as good as desired but the limited evidence should be applied in clinical practice. The evidence gained from RCTs may not be generalizable to this population. Because of the lack of evidence in this group of people, it is sometimes necessary to extrapolate from the evidence in 
the general population with epilepsy. In the future pragmatic study designs may help provide more specific evidence to guide treatment choices. Side effects of medication may present as changes in behaviour in people with ID as they may find is difficult to express the changes they feel due to impairments in communication. Baseline recordings of an individual's usual presentation, routine, and behaviours helps to mitigate for this. While not a focus of this review thought needs to be given to the role of a ketogenic diet and/or a vagus nerve stimulator and its part as adjunct to AEDs. All treatment should be about improving the Quality of Life (QoL) of the person. Consideration could be given to developing a trusting relationship with the patient/carer and where possible ensure QoL discussions is supported by evidence based frameworks such as The International Classification of Functioning, Disability and Health (ICF). This is a classification of health and health-related domains. As the functioning and disability of an individual occurs in a social and environmental context this can influence treatment outcomes significantly. The best improvement in QoL is achieved through seizure reduction, but this cannot be at the cost of intolerable side effects. When there is worsening in seizure control or difficulty in gaining control of seizures thought needs to be given to the physical health, psychological, social, environmental and any care aspects of the individual. Changes in these can significantly influence the seizure domain.

\subsection{Expert Opinion}

The National Institute for Clinical Excellence (NICE) Clinical Guideline on Epilepsies (CG137) considers the challenges of diagnosing epilepsy in people with ID (NICE, 2012) [35]. Establishing seizure activity is complex owing to the increased frequency of physical and neuropsychiatric co-morbidities, and impaired communication. There is a strong association with neurodevelopment disorders such as Autism which may be associated with stereotypical behaviours that can mimic seizure activity. The ILAE clinical definition for epilepsy should be followed [36] and where possible clinicians should attempt to identify seizure type, epilepsy type, and epilepsy syndrome [37].

When initiating AEDs for people with ID, a good guiding principle is to start at a low dose and titrate slowly (Table 5). The initial dose may be far below the guidance for dose titration in the general population and may not achieve a therapeutic level for some time. This process will reduce the risk of dose-related adverse effects. It also allows for ready identification of the 'therapeutic window'. The lowest efficacious dose will also minimise the likelihood of side effects. A drug should not be considered ineffective unless a therapeutic dose has been reached. This should, however, not be at the cost of intolerable side effects. When adding a 'new' AED, good practice dictates that the new drug is added before the old drug is removed. This minimises confusion around symptoms and changes in seizures or side effects during the titration phase of the added drug. As discussed, many people with ID and epilepsy have treatment resistant seizures and therefore the situation is more complex with multiple AEDs. However, the principle of caution should be adopted when prescribing.

Table 5: Other considerations when prescribing AEDs for people with ID developed by working group for the RCPsych CR206 [8]

\begin{tabular}{|l|l|}
\hline AED side effect profile & Neuropsychiatric effect/behaviour:
\end{tabular}

-Behavioural changes are often multifactorial with a wide range of 


\begin{tabular}{|c|c|}
\hline & $\begin{array}{l}\text { influencing factors outside the prescription of AEDs } \\
\text {-Any change in behaviour requires thorough assessment from a variety } \\
\text { of professionals, especially in the context of co-morbid } \\
\text { neurodevelopment disorder such as Autism } \\
\text {-It is appropriate to establish a baseline of behaviour and detailed } \\
\text { history before AED introduction } \\
\text {-AED introduction at low dose with slow titration will help reduce } \\
\text { possible adverse neuropsychiatric effects } \\
\text { Cognition: } \\
\text {-AED effects on cognition may be acute and are usually dose-related } \\
\text {-Older AEDs with poor cognitive profiles such as phenobarbitone and } \\
\text { phenytoin should be avoided where possible } \\
\text {-Lamotrigine appears to demonstrate a positive cognitive profile } \\
\text { Weight } \\
\text { Weight gain-valproate, gabapentin, pregabalin, levetiracetam (atypical) } \\
\text { Weight loss-topiramate, zonisamide } \\
\text { Bone Density: } \\
\text {-People with epilepsy and ID are at high risk of lowered bone density } \\
\text { [38] } \\
\text {-Long term use of enzyme inducing AEDs (phenytoin, phenobarbitone, } \\
\text {-Other AEDs including Valproate may also convey risk }\end{array}$ \\
\hline $\begin{array}{l}\text { Common drug to drug } \\
\text { interactions }\end{array}$ & $\begin{array}{l}\text { Carbamazepine, eslicarbazepine acetate, oxcarbazepine, } \\
\text { phenobarbital, phenytoin, rufinamide, topiramate and perampanel are } \\
\text { all hepatic enzyme-inducing and will impact upon contraceptive } \\
\text { effectiveness (OCP) } \\
\text { The interaction between lamotrigine and valproate medicines is } \\
\text { important as they are a commonly used efficacious combination for } \\
\text { treating generalised seizures. Valproate influences the serum } \\
\text { concentration of lamotrigine through enzyme inhibiting effects. } \\
\text { Therefore in practice adding valproate or increasing the dose of } \\
\text { valproate will increase lamotrigine concentrations leading to the risk of } \\
\text { toxicity. Therefore introduction of Lamotrigine in the presence of } \\
\text { valproate should be done slowly and cautiously. }\end{array}$ \\
\hline Drug preparation & $\begin{array}{l}\text { It is advised that people prescribed certain AEDs should be maintained } \\
\text { on a specific manufacturers' product because of the risk of adverse }\end{array}$ \\
\hline
\end{tabular}




\begin{tabular}{|c|c|}
\hline & $\begin{array}{l}\text { effects or loss of seizure control when changing brands of } \\
\text { preparations. } \\
\text { AEDs are grouped into three categories based on potential risk. The } \\
\text { categories, which are based on: } 1 \text {. therapeutic index, 2. solubility and, } \\
\text { 3. absorption, should be borne in mind when prescribing }\end{array}$ \\
\hline $\begin{array}{l}\text { Treatment for } \\
\text { co-morbid psychiatric } \\
\text { illness }\end{array}$ & $\begin{array}{l}\text { Depression } \\
\text { Selective Serotonin Reuptake Inhibitors (SSRIs) are considered the } \\
\text { first line antidepressant option in patients with epilepsy } \\
\text { Older Tricyclic antidepressants have been shown to have } \\
\text { pro-convulsive effect, especially at high doses } \\
\text { Psychosis } \\
\text { First-generation antipsychotics may have a marginally higher seizure } \\
\text { risk than second-generation antipsychotics } \\
\text { Clozapine, chlorpromazine, loxapine, depot antipsychotics are } \\
\text { associated with highest seizure risk. Aripiprazole was found to have } \\
\text { lower risk when compared to risperidone [39]. }\end{array}$ \\
\hline $\begin{array}{l}\text { Percutaneous } \\
\text { endoscopic gastrostomy } \\
\text { (PEG) }\end{array}$ & $\begin{array}{l}\text { The dose and bioavailability of AEDs is essential to maintaining good } \\
\text { seizure control [40]. } \\
\text { Measurement of serum concentrations of AEDs is of value, where } \\
\text { there is risk of pharmacokinetic variability [41]. Clinicians should } \\
\text { ensure that bioequivalence data is available for formulations and liaise } \\
\text { with a pharmacist where appropriate. }\end{array}$ \\
\hline
\end{tabular}

Table 4 provides a summary of the current evidence base for the use of commonly prescribed AEDs specific to people with epilepsy and ID. It is clear that there is a lack of robust randomised controlled trials specific to this population. There are a number of challenges facing investigators when developing trial designs for people with epilepsy and ID-including recruitment, consent, and ethical considerations. However, we have evidenced the need for such robust evidence for this heterogeneous population in order to ensure that they receive the most appropriate and efficacious treatment with minimum adverse effects. In order to improve the evidence base it is important that clinicians with specialist expertise in working with people with epilepsy and ID are involved is deigning study protocols that are flexible. This may lead to more pragmatic investigations that are 
applicable to real world clinical practice, focusing on AEDs with an established safety and efficacy evidence in the general population.

Clinician's should work collaboratively with patients and their families or care givers to provide individualised treatment. However, this approach must be guided by an evidence base. Attempting to develop shared treatment goals or outcomes measures can be challenging, particularly if individuals have cognitive deficits, impaired communication, and unstable social environments. There is a specific role within this collaboration for the clinician to hold expertise in the prescribing and monitoring of AEDs. In order to do so those working with people with epilepsy and ID need to hold knowledge of AED prescribing and its evidence base in the general population as a baseline. This article serves to add further specific information regarding common AEDs and their utility in epilepsy and ID based on the evidence base and consensus expert opinion.

The Traffic Light System for AEDs should be considered a guide to prescribing clinicians when making treatment choices. Allocation has been weighted by the evidence base over opinion. There is no suggestion that because an AED is given an "Amber" recommendation that it would not be the most appropriate choice for an individual. Many AEDs are widely used in clinical practice regularly with positive outcomes, however they lack a specific evidence base for their use in people with epilepsy and ID. The Traffic Light Coding will be reviewed regularly ( 2 yearly) and updated accordingly as and when new published data is available. With developing evidence it is probable to consider having different traffic light coding systems for Efficacy, Effects on Mood, Effects on Behaviour and Tolerability. 
- The clinical guideline provides a practical approach to medical treatment for people with epilepsy and intellectual disability.

- The current evidence base has been used alongside expert clinical opinion to develop a user friendly 'traffic light' coding system for common antiepileptic drugs.

- Other factors which may influence drug choice are highlighted to ensure treatment is individualised.

- People with epilepsy and intellectual disability are a complex and diverse population with a wide range of co-morbid influencing factors that require consideration.

- The current evidence base for the efficacy and tolerability of antiepileptic drugs in the intellectual disability population is limited and robust investigations are needed. 


\section{References}

1. Kerr M, Linehan C, Thompson R, et al. A White Paper on the medical and social needs of people with epilepsy and intellectual disability: the Task Force on Intellectual Disabilities and Epilepsy of the International League Against Epilepsy. Epilepsia. 2014 Dec;55(12):19026.**Paper highlighting the concerns in the current level of support provided to people with epilepsy and intellectual disability. This paper has initiated a strategic response from the Faculty of Psychiatry of Intellectual Disability, RCPsych.

2. De Boer HM, Mula M, Sander JW. The global burden and stigma of epilepsy. Epilepsy \& behavior. 2008 May 1;12(4):540-6.

3. Ring H. Epilepsy in intellectual disabilities. Adv Clin Neurosci Rehabil. 2013;13:13-5.

4. McGrother CW, Bhaumik S, Thorp CF et al. Epilepsy in adults with intellectual disabilities: prevalence, associations and service implications. Seizure. 2006 Sep 1;15(6):376-86.

5. Kwan P, Arzimanoglou A, Berg AT, et al. Definition of drug resistant epilepsy: consensus proposal by the ad hoc Task Force of the ILAE Commission on Therapeutic Strategies. Epilepsia. 2010 Jun;51(6):1069-77.

6. Turky A, Felce D, Jones G, et al. A prospective case control study of psychiatric disorders in adults with epilepsy and intellectual disability. Epilepsia. 2011 Jul;52(7):1223-30.

7. Robertson J, Hatton C, Emerson E, et al. Prevalence of epilepsy among people with intellectual disabilities: a systematic review. Seizure. 2015 Jul 1;29:46-62.

8. Royal College of Psychiatrists College Report. CR206. London, 2017. ** Full guidelines on the approach to medical treatment for people with epilepsy and intellectual disability.

9. Royal College of Psychiatrists College Report. CR203. London, 2017.

10. Kerr M, Scheepers M, Arvio M, et al. Consensus guidelines into the management of epilepsy in adults with an intellectual disability. Journal of Intellectual Disability Research. 2009 Aug;53(8):687-94.

11. Doran Z, Shankar R, Keezer MR, et al. Managing anti-epileptic drug treatment in adult patients with intellectual disability: a serious conundrum. European journal of neurology. $2016 \mathrm{Jul} ; 23(7): 1152-7 . *$ Overview of the current limited evidence base for antiepileptic drugs for people with intellectual disability.

12. Beavis J, Kerr M, Marson AG, et al. Pharmacological interventions for epilepsy in people with intellectual disabilities. Cochrane database of systematic reviews. 2007(3).

13. Jackson CF, Makin SM, Marson AG, et al. Pharmacological interventions for epilepsy in people with intellectual disabilities. Cochrane Database of Systematic Reviews 2015, Issue 9. Art. No.: CD005399. DOI: 10.1002/14651858.CD005399.pub3. **Full systematic review of evidence base.

14. Guerrini R, Dravet C, Genton P, et al. Lamotrigine and seizure aggravation in severe myoclonic epilepsy. Epilepsia. 1998 May;39(5):508-12.

15. Besag FM. Rufinamide for the treatment of Lennox-Gastaut syndrome. Expert opinion on pharmacotherapy. 2011 Apr 1;12(5):801-6.

16. CANADIAN TASK FORCE ON THE PERIODIC HEALTH EXAMINATION: The periodic health examination. Can. Med. Ass. J. 1979;121:1-93.

17. Motte J, Trevathan E, Arvidsson JF, et al. Lamictal Lennox-Gastaut Study Group. Lamotrigine for generalized seizures associated with the Lennox-Gastaut syndrome. New England Journal of Medicine. 1997 Dec 18;337(25):1807-12.

18. Buchanan N. The efficacy of lamotrigine on seizure control in 34 children, adolescents and young adults with intellectual and physical disability. Seizure. 1995 Sep 1;4(3):233-6.

19. Gidal BE, Walker JK, Lott RS, et al. Efficacy of lamotrigine in institutionalized, developmentally disabled patients with epilepsy: a retrospective evaluation. Seizure. 2000 Mar 1;9(2):131-6. 
20. McKee JR, Sunder TR, Vuong A, et al. Adjunctive lamotrigine for refractory epilepsy in adolescents with mental retardation. Journal of child neurology. 2006 May;21(5):372-9.

21. Marson AG, Al-Kharusi AM, Alwaidh M, et al. The SANAD study of effectiveness of valproate, lamotrigine, or topiramate for generalised and unclassifiable epilepsy: an unblinded randomised controlled trial. The Lancet. 2007 Mar 24;369(9566):1016-26.

22. Kelly K, Stephen LJ, Brodie MJ. Levetiracetam for people with mental retardation and refractory epilepsy. Epilepsy \& Behavior. 2004 Dec 1;5(6):878-83.

23. Brodtkorb E, Klees TM, Nakken KO, et al. Levetiracetam in adult patients with and without learning disability: focus on behavioral adverse effects. Epilepsy \& Behavior. 2004 Apr 1;5(2):231-5.

24. Beavis J, Meek A, Felce D, et al. A prospective multi-centre open label study of the use of levetiracetam as add-on treatment in patients with epilepsy and intellectual disabilities. Seizure. 2009 May 1;18(4):279-84.

25. Andres E, Kerling F, Hamer H, et al. Behavioural changes in patients with intellectual disability treated with brivaracetam. Acta Neurologica Scandinavica. 2018 Sep;138(3):195202.

26. Willems LM, Bertsche A, Bosebeck F, et al. Efficacy, retention, and tolerability of brivaracetam in patients with epileptic encephalopathies: a multicenter cohort study from Germany. Front Neurol. 2018 Jul 23;9:569.

27. Kerr MP, Baker GA, Brodie MJ. A randomized, double-blind, placebo-controlled trial of topiramate in adults with epilepsy and intellectual disability: impact on seizures, severity, and quality of life. Epilepsy \& Behavior. 2005 Nov 1;7(3):472-80.

28. Crawford P, Brown S, Kerr M, Parke Davis Clinical Trials Group. A randomized open-label study of gabapentin and lamotrigine in adults with learning disability and resistant epilepsy. Seizure. 2001 Mar 1;10(2):107-15.

29. Shankar R, Henley W, Wehner T, et al. Perampanel in the general population and in people with intellectual disability: Differing responses. Seizure. 2017 Jul 1;49:30-5.

30. Flores L, Kemp S, Colbeck K, et al. Clinical experience with oral lacosamide as adjunctive therapy in adult patients with uncontrolled epilepsy: a multicentre study in epilepsy clinics in the United Kingdom (UK). Seizure. 2012 Sep 1;21(7):512-7.

31. Kaski M, Heinonen E, Sivenius J, et al. Treatment of epilepsy in mentally retarded patients with a slow-release carbamazine preparation. Journal of Intellectual Disability Research. 1991 Jun;35(3):231-9.

32. Shorvon S, Baulac M, Cross H, et al. Task Force on Status Epilepticus of the ILAE Commission for European Affairs. The drug treatment of status epilepticus in Europe: consensus document from a workshop at the first London Colloquium on Status Epilepticus. Epilepsia. 2008 Jul;49(7):1277-85.

33. Gauthier AC, Mattson RH. Clobazam: a safe, efficacious, and newly rediscovered therapeutic for epilepsy. CNS neuroscience \& therapeutics. 2015 Jul;21(7):543-8.

34. Isojärvi JI, Tokola RA. Benzodiazepines in the treatment of epilepsy in people with intellectual disability. Journal of intellectual disability research: JIDR. 1998 Dec;42:80-92.

35. NICE clinical guideline 137, The epilepsies: the diagnosis and management of the epilepsies in adults and children in primary and secondary care. 2012.

36. Fisher RS, Acevedo C, Arzimanoglou A, et al. ILAE official report: a practical clinical definition of epilepsy. Epilepsia. 2014 Apr;55(4):475-82.

37. Scheffer IE, Berkovic S, Capovilla G, et al. ILAE classification of the epilepsies: position paper of the ILAE Commission for Classification and Terminology. Epilepsia. 2017 Apr;58(4):512-21.

38. Burke É, Carroll R, O'Dwyer M, et al. Quantitative examination of the bone health status of older adults with intellectual and developmental disability in Ireland: a cross-sectional nationwide study. BMJ open. 2019 Apr 1;9(4):e026939. 
39. Wu CS, Wang SC, Yeh IJ, et al. Comparative risk of seizure with use of first-and secondgeneration antipsychotics in patients with schizophrenia and mood disorders. The Journal of clinical psychiatry. 2016 May;77(5):e573-9.

40. Jory C, Shankar R, Oak K, et al. Going down the tubes! Impact on seizure control of antiepileptic medication given via percutaneous feeding tubes. Epilepsy \& Behavior. 2017 Sep 1;74:114-8.

41. Patsalos PN, Berry DJ, Bourgeois BF, et al. Antiepileptic drugs — best practice guidelines for therapeutic drug monitoring: a position paper by the subcommission on therapeutic drug monitoring, ILAE Commission on Therapeutic Strategies. Epilepsia. 2008 Jul;49(7):1239-76. 